\title{
Predictors of the Degree of Positive Earnings Surprises
}

\author{
Rebecca Abraham, Charles Harrington \\ Huizenga College of Business, Nova Southeastern University, Fort Lauderdale, FL, USA \\ Email:abraham@nova.edu,charlieh@nova.edu
}

Received 24 April 2016; accepted 27 June 2016; published 30 June 2016

Copyright (C) 2016 by authors and Scientific Research Publishing Inc.

This work is licensed under the Creative Commons Attribution International License (CC BY). http://creativecommons.org/licenses/by/4.0/

(c) (i) Open Access

\begin{abstract}
This study identifies the predictors of positive earnings surprises at varying levels of earnings surprises under strong and weak business conditions (2014 and 2010, respectively). It measures the impact on surprises of a unique and diverse set of predictors such as analyst coverage and industry type which are security characteristics and sales and cash flow that emanate from financial statements. The study employs technology stocks that were found on the NASDAQ as such stocks have reported high positive earnings surprises from 2013-2015 [1]. The entire population of positive earnings surprises for 8316 NASDAQ stocks in 2010 and 2014 was used. Event studies were used to measure abnormal return and abnormal volume at earnings announcement, while multiple regressions tested the influence of the predictors of positive earnings surprises including number of analysts, sales, cash flow and industry type. Number of analysts significantly predicted positive earnings surprises of $<20 \%, 21 \%-30 \%, 31 \%-100 \%$ and $>100 \%$ regardless of business condition, while sales and industry type showed similar results for weak business conditions. Cash flow explained positive earnings surprises in the $21 \%-30 \%$ earnings surprises range for weak business conditions, while industry type was significant in the $<20 \%$ and $>100 \%$ earnings surprises categories for strong business conditions.
\end{abstract}

\section{Keywords}

Positive Earnings Surprise, Analyst Coverage, Cash Flow, Industry Type

\section{Introduction}

Earnings are an accounting measure consisting of net profit after taxes, or a snapshot of firm performance. Conceptually, a firm produces goods and services, sells them for sales revenue, incurs expenses and generates profit or earnings. The market rewards positive profits with higher stock returns. The firm may pay varying portions of 
its profit in dividends to shareholders so that the value of the firm may be measured as the present value of the stream of future cash flows derived from its prospective earnings. Information asymmetry abounds with management having full information about the source of profitable endeavors and the financial markets using limited publicly-available resources to forecast the future performance of the firm. Firms that exceed earnings estimates are credited with achieving positive earnings surprises, while those that fail to meet earnings estimates have negative earnings surprises. Stock price reaction is intense with positive earnings surprises earning up to $19 \%$ in excess returns and negative earnings surprises resulting in 16\% in abnormal returns below the threshold for 1965-2002 data [2] [3].

Certain technology-intensive firms have reported record earnings surprises including Apple with 8 quarters of earnings surprises from 2013-2015, Amazon at 15\% positive earnings surprise, and Facebook at 35\% positive earnings surprise in the fourth quarter of 2015 [1]. Several research questions abound. Is the high visibility of these firms from close following by a large number of financial analysts responsible for an increase in managerial motivation to repay debt and reduce costs, thereby generating earnings surprises? Is sales growth from the worldwide customer base on the Internet driving earnings surprises? Are higher cash flows the underlying reason for earnings surprises? Are such earnings surprises specific to certain industries or can they be generalized to other industries? It is to these questions that this study is directed.

Our primary objective is to determine the predictors of positive earnings surprises which describe the information in financial statements that fuels higher stock returns. Predictors include 1) sales whose growth may be related to the persistence of earnings, 2) cash flow as positive contemporaneous cash flows may lead to a stream of positive future cash flows, 3) type of industry to account for the excessively large earnings surprises in certain industries, and 4) analyst coverage as the larger the number of analysts providing earnings estimates of a particular stock, the greater the expectations of superior performance. Given that more information about the firm increases investor knowledge and expectations, performance may be elevated, positive earnings surprises may result and higher stock returns may ensue. We employ multiple regressions of these predictors on the extent of positive earnings surprises to determine the relative importance of each predictor with the predictor with the most highly significant regression coefficient being the most important predictor. Such information is of both theoretical and practical interest that it permits academicians to trace the path from the accounting variables of sales, cash flow, industry and visibility to stock returns, while investors would then identify sales growth, cash flow, type of industry and analyst coverage as characteristics of stocks with high returns which may be included in portfolios.

We confine this investigation of earnings to positive earnings surprises which are informative in their ability to increase investor expectations of future firm profitability, increase expectations of future dividends and in turn, the market value of the firm with a stream of successively higher stock prices. Signaling theory maintains that the value of a firm consists of a combination of its certainty equivalent level of earnings and uncertain cash flow proxies such as dividends. A positive earnings surprise indicates that the firm has surpassed its threshold level of earnings. Thus, the positive earnings surprise acts as a signaling device that the firm undertook positive corporate actions such as increased investment in advertising and promotion, new product development or new market penetration. There is unique mapping from the positive earnings surprise to earnings to firm valuation, so that increased earnings enhance firm values [4].

This study employs securities traded on the NASDAQ, which has 3300 company listings with considerable representation from computer and biotechnology firms which have experienced earnings surprises in excess of $100 \%$. We measure the aforementioned predictive effects in intervals for positive earnings surprises of $<20 \%$, $21 \%-30 \%$, 31\% - 100\% and >100\%. We employ two sources of data, for 2010 and 2014, to evaluate the effect of different market conditions on the relationships of firm performance with earnings surprises. In 2010, the U.S. economy was emerging from a severe downturn and stock market correction. In the uncertain economic environment following these conditions, i.e. in 2010, we conjecture that businesses were more likely to uphold performance-based criteria such as sales and cash flow. In 2014, five years after the economic recovery, the surge of the Dow Jones Industrial Average from 7000 in March 2009 to 17,000 in December, 2014 and 15.89\% annualized growth in the NASDAQ [5], it appeared that the economy had catapulted into growth so that less performance-based variables such as firm visibility measured by analyst coverage and type of industry dominated in explaining positive earnings surprises. Our recognition of the influence of business conditions on stock returns is in accordance with [6] who observed a high risk premium in low-grade bonds and stocks during poor economic conditions with low consumption and a high rate of business defaults. In contrast, there was a low risk premium 
in high-grade bonds during strong economic conditions of increased consumption and a reduction in business defaults.

\section{Hypotheses Development}

\subsection{Analysts' Coverage Influences Earnings Surprises}

Security analysts are tasked with following 10 - 20 firms and making recommendations to purchase, sell or hold the stock of these firms. These job demands impose a monitoring responsibility on the analyst, i.e. the analyst monitors the activities of management and disseminates information about management's ability to achieve organizational goals. Thus, security analysts reduce agency costs whereby managers prioritize their own self-interest above the firm's objectives [7]. [8] obtained empirical support for analysts' reduction of agency costs by measuring abnormal gross returns $>4 \%$ for stocks selected based on analyst recommendations which in turn, led to higher stock prices on the day of release of the recommendations [9]. The larger the number of analysts covering a security, the more scrutiny there will be over managerial actions and the greater the publicity accorded to managerial infractions. There is evidence that such an increase in analyst coverage increases firm valuations. [10] empirically tested the relationship between the number of analysts and firm valuation (measured by Tobin's Q) and found a positive relationship. These results were supported by [11] who found that number of analysts increased Tobin's Q after controlling for the effects of managerial ownership. [12] posited that research and development-intensive firms are more likely to be followed by more analysts because they are perceived to be of higher quality. It may be inferred that as high quality firms are more likely to outperform earnings estimates, more analysts are motivated to cover them further stimulating positive earnings surprises. [13] set forth that as many investors acquire familiarity with a firm through the information revealed by analysts' forecasts. We conjecture that such expansion of investor knowledge leads to positive earnings surprises.

Stakeholder theory maintains that multiple stakeholders have contractual relationships of varying intensity with the firm [14]. The challenge of identifying the stakeholders and their interests is partly met by security analysts' forecasts which include descriptions of the firm's interactions with these groups [15]. These interactions result in analysts obtaining a rich and comprehensive database of information from diverse sources including industry associations, government macroeconomic data, press releases, regular conferences with top management, visiting plants, and conferring with operations-level managers across departments in order to identify the firm's competitive advantage. We maintain that the extensive repertoire of knowledge increases the effectiveness of the analysts' monitoring role, promotes firm investment in projects with long-term profit potential and increases earnings causing earnings surprises.

Research on celebrity firms provides insight into the extent of analyst coverage symbolizing firm visibility. Celebrity firms are mentioned frequently in the media through descriptions of their organizational culture, leadership and identities arousing their audience to fantasize, gossip and affiliate themselves with these firms [16]. Oracle and Amazon are examples of celebrity firms. Expectations of future performance from these firms are heightened so that they are expected to deliver superior performance in the future possibly by exceeding earnings estimates through positive earnings surprises. To maintain their celebrity status, such firms strive to deliver positive earnings surprises. Such positive earnings surprises were viewed as affectively positive stimuli whose effects are strengthened by the positive affective frame of the celebrity [17].

H1: The greater the number of analysts following a security, the greater its potential for positive earnings surprise.

\subsection{Sales Indicates Earnings Persistence and Future Performance}

[18] maintain that realized strategy emanates from the original sequence of decisions. However, outcomes that deviate from original plans are plausible, being designated as unrealized sales. New challenges are incorporated in emergent sales opportunities. Analysts may respond to unrealized or emergent sales opportunities by revising their original earnings forecasts. In the event that such revisions fail to capture all of the elements of either unrealized or emergent sales opportunities, actual earnings deviate from analysts' forecasts in the form of positive earnings surprises. The iPhone 1 may be a case of emergent sales potential. Given the market's excitement for a smartphone with data processing capabilities that was vastly more functional than the phones of its time, unexpected earnings surpassed even the most optimistic analysts' forecasts, elevating stock returns. [19] isolated un- 
expected information in earnings announcements by using cross-sectional regressions on the announcement day for both a stock sample and a bond sample. They obtained significantly higher abnormal returns than studies that failed to separate emergent or unrealized sales from existing sales [20]-[22], suggesting that it is the unexpected information in positive earnings surprises that generates abnormal stock returns. [23] theorized that a sequential information arrival process prevails at earnings announcement. New information is phased into the financial markets at different points in time, resulting in periods of highly abnormal stock returns. Multiple empirical studies have observed higher stock returns with the introduction of new information into earnings. [24] found that average returns were 4 - 5 times larger in time periods during which new earnings information was announced. [25] identified a different stock price adjustment process for unrealized information set forth in analysts' revisions of earnings estimates. [26] observed the largest adjustment of stock prices to the most favorable earnings news along with higher trading volume upon announcement of unexpected earnings for a sample of NYSE stocks.

[27] theorized that product differentiation achieves competitive advantage which increases demand for a firm's products and acts as a barrier to entry in that competitors cannot easily duplicate this strategy. Differentiated products achieve sustained revenue growth. In contrast, competitors can more easily implement cost-reduction measures, such as reductions in benefits and increasing operational efficiency. Sales increases have unlimited upside potential unlike cost reductions which have a definite floor below which further reductions harm operational efficiency [28]. [28] observed that earnings response coefficients for sales-supported growth were higher than similar coefficients for cost-reduction oriented growth.

[29] set forth the expectations adjustment hypothesis to eontextualize the roles of sales forecasts and earnings forecasts in predicting firm performance. Managers set original earnings and performance expectations which may be revised as new information is released. Sales forecasts contain the incremental information about future earnings that is not contained in earnings estimates. R\&D-intensive firms are engaged in radical innovation or the production of a succession of new products. The profit potential of such products is uncertain, or the volatility of earnings is greater for high R\&D intensity companies. As the precision of analysts' earnings forecasts is lower for such firms, positive earnings surprises are less likely to be sustained. For instance, in a quarter in which highly anticipated products are launched, sales growth accelerates. Sales growth during the following quarter may not be realized as the novelty of the products wears off. A positive earnings surprise may still be realized if costs are postponed in the following quarter. In such cases, sales growth rather than earnings growth indicates future profit potential and in turn, firm performance and higher stock returns. [30] demonstrated that sales dominate earnings as predictors of stock returns in high R\&D intensity companies with respect to low R\&D intensity companies. For firms engaged in oligopolistic competition, increases in market share are related to sales increases. For example, in the market for international airline travel, oligopolistic competition prevails with domination by 3 - 4 firms. An increase in tourist travel has resulted in a steady growth in the number of travelers, or increases in market share for the airlines servicing these routes. The sales growth for these airlines is informative in that it reveals a shift in socioeconomic status leading to the leisure choice for travel in a new market segment. In this regard, [30] observed that for oligopolistic firms in the fourth fiscal quarter, sales surprises had a more powerful impact on stock returns than earnings surprises without sales surprises.

H2: Higher firm sales results in positive earnings surprises.

\subsection{Cash Flow Generates Unique Information in Explaining Earnings}

At its most basic level, cash flow meets operating expenses, so that increased cash flow increases profits or earnings. Cash flow has clear accounting identity in that the reduction of plant and equipment costs from cash flow indicates the amount of resources available for financial outflows such as dividends, acquisitions or buybacks [31]. Cash generated by the firm's operations is an objective quantity, i.e. represented by the balance in a bank account. It cannot be manipulated as the account balance indicates its true level. It is not dependent upon deferred receipts, accruals and allocations [32] [33]. Cash makes a unique information contribution to earnings, so that some element of positive earnings surprises may be due to excess cash. [34] created a cash flow-based trading strategy, finding the long-term persistence of cash flows in influencing earnings resulting in abnormal excess stock-returns for cash-rich firms over the more transitory stock returns for high accrual firms.

H3: Stronger operating cash flows contribute to positive earnings surprises. 


\subsection{Industry Type Influences Positive Earnings Surprises}

[35] set forth an investor rationality model in which investors overemphasize salient information that is vivid and in the form of cases and anecdotes rather than factual or statistical information. A series of studies have empirically confirmed such overweighting of extreme events and underweighting of facts [36]-[38]. [39] drew on the work of [40] to advance reasons for investor acceptance of industry news over technical information. Industry news is emotionally interesting, creates images, spatially close, and reinforces existing images in the memory of the recipient. Additionally, industry news is thought-provoking in that it provides additional information about the firm that must be digested leading to such news capturing attention for a longer period of time than mere numbers. We are referring to industry innovations rather than product news at the firm level. For example, two pharmaceutical firms have created drugs to treat elevated cholesterol levels in patients who are resistant to the common statin drugs. The breakthrough biotechnology is of relevance to this study, not the specifications of the medicines. [39]'s measurement of overreaction in stock prices found a full 3.08\% point increase in stock returns during all possible 70-day return periods from 1995-2001 for pharmaceutical industry news.

H4: Industry type influences positive earnings surprises.

\section{Data and Methodology}

A population of 8316 stocks trading on the NASDAQ in 2010 was identified. This population was tracked for the following five years from 2010-2014 by identifying the dates of quarterly earnings announcement per quarter. Event studies were conducted to capture the cumulative abnormal returns found on annual data by year, i.e. there were 5 separate event studies for each year as reported in Table 1.

Both daily return and volume event studies were conducted during the earnings announcement periods of days -2 to +2 for quarterly earnings announcements on the full population of 8316 NASDAQ stocks for which PERMNO identifiers and date of announcement were available for 2010-2014. Specifically as shown in Table 1, on day -1 , the day before earnings announcement, and on day 0 , the day of earnings announcement, highly significant coefficients on both abnormal returns and abnormal volume were obtained for every year. Values of the coefficient on cumulative abnormal return $=0.17, \mathrm{p}<0.001$, and the coefficient $=39.41, \mathrm{p}<0.001$ for cumulative abnormal volume, day -1.2010 , and coefficient on cumulative abnormal return $=0.78, \mathrm{p}<0.001$ and the coefficient $=85.12, \mathrm{p}<0.001$ for cumulative abnormal volume day 0 , 2013, suggest that traders capitalize on the price run-up on favorable news contained in positive earnings surprises both on rumor and at actual announcement. Lingering stock price increases remain on day +1 , with significant coefficients for each year on day +1 such as the return coefficient $=0.84, \mathrm{p}<0.001$, and volume coefficient $=58.59, \mathrm{p}<0.001$ on day +1 for 2012. Traders may still take advantage of abnormal stock prices increases on day +1 . However, on day +2 , these gains dissipate with no significant abnormal returns for three of five years (i.e., 2010-2012).

Data for 2010 and 2014 were subjected to further analyses to test the hypotheses. Market capitalization was included as a control variable to remove any variation in earnings surprise from the employment of stocks of firms of varying size. Zacks Investment Research provided quarterly values for the percentage of positive earnings surprises and market capitalization, COMPUSTAT was the source of quarterly sales and cash flow, while EVENTUS generated industry SIC codes to identify Industry Type. Market capitalization was included as a

Table 1. Results of event studies of the announcement period of 2010-2014 positive earnings surprises.

\begin{tabular}{cccccc}
\hline Day & $\begin{array}{c}2010 \text { Abnormal } \\
\text { Return and } \\
\text { Abnormal Volume } \\
(\%)\end{array}$ & $\begin{array}{c}\text { 2011 Abnormal } \\
\text { Return and } \\
\text { Abnormal Volume } \\
(\%)\end{array}$ & $\begin{array}{c}2012 \text { Abnormal } \\
\text { Return and } \\
\text { Abnormal Volume } \\
(\%)\end{array}$ & $\begin{array}{c}2013 \\
\text { Abnormal Return } \\
\text { and Abnormal } \\
\text { Volume (\%) }\end{array}$ & $\begin{array}{c}\text { 2014 Abnormal } \\
\text { Return and } \\
\text { Abnormal Volume } \\
(\%)\end{array}$ \\
\hline-2 & $0.10^{* *}, 29.53^{* * *}$ & $0.04^{* *},-6.00^{* * *}$ & $0.02,-2.77^{* * *}$ & $0.03,33.86^{* * *}$ & $0.08^{* * *},-3.13^{* * *}$ \\
-1 & $0.17^{* *}, 39.41^{* * *}$ & $0.04^{*}, 4.31^{* * *}$ & $0.03,7.59^{* * *}$ & $0.00,46.17^{* * *}$ & $0.11^{* * *}, 9.62^{* * *}$ \\
0 & $0.68^{* * *}, 73.37^{* * *}$ & $0.71^{* * *}, 40.28^{* * *}$ & $0.78^{* * *}, 45.45^{* * *}$ & $0.78^{* * *}, 85.12^{* * *}$ & $0.63^{* * *}, 45.63^{* * *}$ \\
+1 & $0.82^{* * *}, 86.87^{* * *}$ & $0.90^{* * *}, 54.92^{* * *}$ & $0.84^{* * *}, 58.59^{* * *}$ & $1.06^{* * *}, 103.62^{* * *}$ & $0.89^{* * *}, 63.40^{* * *}$ \\
+2 & $0.06,61.51^{* * *}$ & $-0.03,25.63^{* * *}$ & $0.04,27.99^{* * *}$ & $0.17^{* * *}, 71.11^{* * *}$ & $0.06^{* * * *}, 31.75^{* * *}$ \\
\hline
\end{tabular}

${ }^{*} \mathrm{p}<0.05,{ }^{* *} \mathrm{p}<0.01,{ }^{* * *} \mathrm{p}<0.001$. 
proxy for size in order to prevent any confounding effect on the results from size variations in the firms under consideration. Four identical ordinary least squares multiple regression formulations were employed in the earnings surprise intervals of $<20 \%, 21 \%-30 \%, 31 \%-100 \%$ and $>100 \%$ to test hypothesis 1 . The formulation may be stated as follows:

$$
\begin{aligned}
\text { Positive Earnings Surprise }= & \alpha+\beta_{1} \text { Number of Analysts }+\beta_{2} \text { Industry Type } \\
& +\beta_{3} \text { Sales }+\beta_{4} \text { Cash Flow }+\beta_{5} \text { Market Capitalization }
\end{aligned}
$$

Sixteen identical ordinary least squares multiple regressions were performed using Equation (1) in order to test hypotheses 2 and 3. Each regression was repeated for the electronic computer, accident and health insurance, and air transport industries for the categories of $<10$ Analysts and $>10$ Analysts in order to separate the effects of sales and cash flow on earnings surprises from industry and the number of analysts. An additional twelve multiple regressions were performed by industry in each earnings surprise interval with Equation (1) to test hypothesis 4.

\section{Results}

Hypothesis 1 was supported for both 2010 and 2014 data, with number of analysts significantly explaining positive earnings surprises for all levels of earnings surprise including 20\%, 21\% - 30\%, 31\% - 100\% and > 100\% at the highest $\mathrm{p}<0.001$ level of significance (see Table 2). Number of analysts is not dependent on business conditions given that it demonstrates significant effects during the varying economic conditions of 2010 and 2014. Further analysis of 2010 date and 2014 data undertaken in Table 3 and Table 4 respectively, shows that for 3 different industries, i.e. electronic computers (a highly competitive industry based on radical innovation), accident and health insurance (a competitive industry with an altered environment due to the implementation of the Affordable Care Act) and air transport (a competitive industry with new entrants and declining input costs in reduced fuel prices), number of analysts adds unexpected information to that contained in earnings estimates. This information may be about forthcoming managerial action obtained by analysts upon their monitoring of managers, investment cues to increase investor cognizance or market awareness of increased visibility of the securities as more analysts are following them.

Hypothesis 2 was supported for 2010 data, though not for 2014, with sales significantly explaining the variation in positive earnings surprises (see Table 2) in the positive earnings surprise size categories of < 20\%, $21 \%$ $30 \%$ and $31 \%-100 \%$. It is possible that the unfavorable business climate of 2010 led to an emphasis on firms meeting sales targets, a condition that was not upheld in the more favorable business environment of 2014. For the $>100 \%$ earnings surprise level, the influence of sales on earnings surprise may be industry-specific in that significant effects are only observed for the electronic computer industry (see Table 4).

Table 2. Results of regressions of varying levels of positive earnings surprises on industry, number of analysts, sales and

\begin{tabular}{|c|c|c|}
\hline Earnings Surprise (\%) & 2010 & 2014 \\
\hline$<20 \%$ & $\begin{array}{c}\text { Industry }=7.82 \times 10^{-5^{* * *}} \\
\text { Number of Analysts }=2.23 \times 10^{3 * * *} \\
\text { Sales }=4.31 \times 10^{6 * * *} \\
\text { Market Capitalization }=4.76 \times 10^{-8^{* * *}}\end{array}$ & $\begin{array}{c}\text { Industry }=1.69 \times 10^{-5^{*}} \\
\text { Number of Analysts }=0.02^{* * *}\end{array}$ \\
\hline $21 \%-30 \%$ & $\begin{array}{c}\text { Industry }=6.09 \times 10^{-5^{* * *}} \\
\text { Number of Analysts }=3.53 \times 10^{3^{* * *}} \\
\text { Sales }=3.5 \times 10^{6 * * *} \\
\text { Market Capitalization }=3.67 \times 10^{-8} \\
\text { Cash Flow }=3.67 \times 10^{-6^{*}}\end{array}$ & Number of Analysts $=0.02^{* * *}$ \\
\hline $31 \%-100 \%$ & $\begin{array}{c}\text { Industry }=2.52 \times 10^{-3^{* * *}} \\
\text { Number of Analysts }=2.93 \times 10^{3^{* * *}} \\
\text { Sales }=1.54 \times 10^{6^{*}}\end{array}$ & Number of Analysts $=7.82 \times 10^{-3^{* * *}}$ \\
\hline$>100 \%$ & $\begin{array}{c}\text { Industry }=2.55 \times 10^{-5^{* * *}} \\
\text { Number of Analysts }=0.01^{* * *}\end{array}$ & Industry $=5.05 \times 10^{-6^{* * *}}$ \\
\hline
\end{tabular}
market capitalization (2010 and 2014). 
Table 3. Results of regressions of varying levels of positive earnings surprises for the computer, health insurance and air transport industries (2010).

\begin{tabular}{|c|c|c|c|c|c|c|}
\hline $\begin{array}{l}\text { Earnings } \\
\text { Surprise } \\
\text { (\%) }\end{array}$ & $\begin{array}{c}\text { Electronic } \\
\text { Computers } \\
\text { Analysts }<10\end{array}$ & $\begin{array}{c}\text { Electronic } \\
\text { Computers } \\
\text { Analysts }>10\end{array}$ & $\begin{array}{l}\text { Accident and Health } \\
\text { Insurance } \\
\text { Analysts }<10\end{array}$ & $\begin{array}{l}\text { Accident and Health } \\
\text { Insurance } \\
\text { Analysts }>10\end{array}$ & $\begin{array}{l}\text { Air Transport } \\
\text { Analysts }<10\end{array}$ & $\begin{array}{c}\text { Air } \\
\text { Transport }>10\end{array}$ \\
\hline$<20$ & N/A & Sales $=6.95 \times 10^{-6^{* * *}}$ & Sales $=6.98 \times 10^{-6^{* * * *}}$ & Sales $=6.95 \times 10^{-6 * * *}$ & Sales $=6.77 \times 10^{-6^{* * *}}$ & Sales $=6.95 \times 10^{-6^{* * *}}$ \\
\hline $21-30$ & $\begin{aligned} \text { Sales } & =5.49 \times 10^{-6^{* * *}} \\
\text { Cash } & =4.70 \times 10^{-6^{* *}}\end{aligned}$ & $\begin{aligned} \text { Sales } & =5.44 \times 10^{-6^{* * * *}} \\
\text { Cash } & =4.84 \times 10^{-6^{* *}}\end{aligned}$ & $\begin{aligned} \text { Sales } & =5.49 \times 10^{-6^{* * *}} \\
\text { Cash } & =4.84 \times 10^{-6^{* * *}}\end{aligned}$ & $\begin{aligned} \text { Sales } & =5.44 \times 10^{-6^{* * * *}} \\
\text { Cash } & =4.84 \times 10^{-6^{* *}}\end{aligned}$ & $\begin{aligned} \text { Sales } & =5.49 \times 10^{-6^{* * * *}} \\
\text { Cash } & =4.76 \times 10^{-6^{* *}}\end{aligned}$ & $\begin{aligned} \text { Sales } & =5.44 \times 10^{-6^{* * * *}} \\
\text { Cash } & =4.84 \times 10^{-6^{* *}}\end{aligned}$ \\
\hline $31-100$ & N/A & Sales $=2.26 \times 10^{-6^{* * *}}$ & Sales $=1.83 \times 10^{-6^{* * *}}$ & Sales $=2.27 \times 10^{-6 * * *}$ & Sales $=2.31 \times 10^{-6^{* * *}}$ & N/A \\
\hline$>100$ & Sales $=1.83 \times 10^{-6^{* *}}$ & N/A & N/A & N/A & Sales $=1.79 \times 10^{-6^{* * *}}$ & N/A \\
\hline
\end{tabular}

Regressions were conducted with predictors of sales, cash flow and market capitalization. Only significant predictors are reported. ${ }^{*} \mathrm{p}<0.05,{ }^{* *} \mathrm{p}<0.01,{ }^{* * *} \mathrm{p}<$ 0.001 .

Table 4. Results of regressions of varying levels of positive earnings surprises on number of analysts for the electronic computer, accident and health insurance and air transport industries (2014).

\begin{tabular}{cccc}
\hline Earnings Surprise (\%) & Electronic Computers & Accident and Health Insurance & Air Transport \\
\hline$<20$ & Number of Analysts $=0.02^{* * *}$ & Number of Analysts $=0.02^{* * *}$ & Number of Analysts $=0.02^{* * *}$ \\
$21-30$ & Number of Analysts $=0.02^{* * *}$ & Number of Analysts $=7.22^{* * *}$ & Number of Analysts $=7.22^{* * *}$ \\
$31-100$ & Number of Analysts $=7.68 \times 10^{-3^{* * *}}$ & Number of Analysts $=7.67 \times 10^{-3^{* * *}}$ & Number of Analysts $=7.68 \times 10^{-3^{* * *}}$ \\
$>100$ & Number of Analysts $=5.97 \times 10^{-3^{* *}}$ & N/A & N/A \\
\hline
\end{tabular}

Regressions were conducted with predictors of number of analysts, sales, cash flow and market capitalization. Only significant relationships are reported. ${ }^{*} \mathrm{p}<$ $0.05,{ }^{* *} \mathrm{p}<0.01,{ }^{* * *} \mathrm{p}<0.001$.

As shown in Table 2, Hypothesis 3 was supported in the $21 \%$ - 30\% positive earnings surprise category of $21 \%$ - 30\% for 2010 data, with cash flow significantly determining earnings surprise. This result was maintained across the three industries under consideration with coefficients ranging from $4.70 \times 10^{-6}, \mathrm{p}<0.01$ to $4.84 \times$ $10^{-6}, \mathrm{p}<0.01$. Firms with moderate levels of earnings surprise were expected to maintain acceptable levels of cash flow from operations to satisfy management and investors of their financial viability during uncertain economic times. Additionally, perhaps these firms delayed investment in plant and equipment to reduce fixed operating costs and boost cash flow.

From Table 2, Hypothesis 4 with the significant influence of industry type on positive earnings surprises was supported in all earnings surprise categories for 2010 data and the $<20 \%$ and $>100 \%$ size categories for 2014 data. Unexpected information in the electronic computer industry, accident and health insurance industry and air transport industry increase actual profits over original estimates. Such information may be released by an industry association or government-policy change that affects all firms in the industry.

\section{Conclusions}

This study has found that the number of analysts predicts positive earnings surprises under strong and weak business conditions across three industries and four levels of earnings surprises. This is the single strongest predictor of positive earnings surprises. This study envisions security analysts as information intermediaries who monitor the firm with a view towards curbing the unproductive usage of firm capital and the incurring of agency costs. As agents of the firm rather than owners, managers may be prone to accept low-return projects or engage in wasteful expenditure on perks that promise prestige and prominence for themselves. However, they may be reluctant to undertake such investments if they are aware that their actions are being monitored by a large number of analysts who are likely to communicate their findings to other stakeholders such as regulators, the government, industry associations, marketers, etc. This disciplining function may lead to management making investments that yield long-term benefits to the firm and in turn, positive earnings surprises. Over time, a succession of superior earnings may result in higher firm valuation as investors reward the firm's growth strategies over time (see [10] and [11], for empirical evidence of increased Tobin's Q's as a measure of firm valuation following increased following by analysts). We envision an intermediate role for positive earnings surprises in 
this process with an increase in number of analysts yielding positive earnings surprises, which results in higher firm valuations. Future research must be undertaken to test this sequential relationship.

The celebrity status of a firm may contribute to positive earnings surprises. Intuitively, innovative technology firms that produce a stream of new products are expected to maintain their position. The employees of such firms are usually sufficiently motivated to surpass performance expectations or achieve positive earnings surprises. From a theoretical standpoint, we may relate their actions to the Hawthorne Effect [41]. In an experiment at the Hawthorne plant of the Lincoln Electrical Works, the shining of light increased worker motivation as did plunging the factory into darkness. The researchers concluded that productivity increased due to the extra attention being paid to the workers regardless of any independent effect of light. By the same token, the extra attention paid to celebrity firms may motivate employees to progressively superior performance or positive earnings surprises.

This study has contributed to the literature on the expectations adjustment hypothesis. Analysts adjust expectations based upon the information contained in unrealized strategy or emergent strategy. As this study upholds the importance of having more analysts to uncover unexpected information, it may be that emergent and unrealized strategies are highly nebulous, so that input from a larger number of analysts is needed to probe the firm's governance mechanisms, analyze top management intentions and communicate with suppliers, customers, distributors and other stakeholder groups. For R\&D-intensive firms, such as those traded on the NASDAQ, even more analysts may be necessary to glean the possibility of success of new products and untested new technologies in a highly competitive environment. Further research must be conducted to determine the exact range of analyst coverage by industry.

Unexpected information contained in positive earnings surprises pertains to both sales and cash flows subject to business conditions in poor economic times, strong sales bolster confidence that positive earnings will persist into the future at all levels of earnings surprises. In similarly poor economic environments, cash flows provide information that long-term earnings will persist for earnings surprises in the $21 \%$ - $30 \%$ range. Sales and cash flow act as signals of positive earnings in subsequent quarters suggesting the possibility of continually increasing stock returns.

This study identifies industry type as a predictor of positive earnings surprises. We extend our analysis to the electronic computer, accident and health insurance and air transport industries. In each industry, there is industry-specific news contained in positive earnings surprises that is vivid enough to be retained by investors who purchase industry securities based on that information. Anecdotes of the extraordinary capabilities of new robots and other devices in the computer industry, the removal of preexisting conditions in health insurance, and emergency airplane landings that saved lives in air transport are uplifting in nature, possibly leading to positive earnings surprises and sending buy signals to investors in these securities.

This study adds to the sparse literature on determinants of varying levels of earnings surprises. [42] set forth one of the few studies that evaluates earnings surprises in terms of varying levels, such as small (about 5\% $10 \%$ ) and large (>10\%) earnings surprises. They observed that dispersion of analysts' forecasts was significantly associated with earnings surprises. Firms with small earnings surprises have minimal dispersion of analysts' forecasts, or analysts achieve consensus on the earnings estimate easily. Firms with large earnings surprises have much higher dispersion suggesting idiosyncratic volatility. This suggests that the predictors of earnings surprises may influence large earnings surprises differently from small earnings surprises. We use a finer distinction of levels of earnings surprises with 4 categories rather than the dual small-large distinction and employ 4 determinants (number of analysts, sales, cash flow, and industry type) to complement the single (dispersion of analysts' forecasts variable) in their examination. Our findings taken together posit that a larger number of analysts with minimal consensus of opinion on final earnings forecasts significantly influence large earnings surprises.

Earnings surprises must be examined in terms of surprise categories as the hypotheses are differentially supported across size categories. The $>100 \%$ earnings surprise category requires further analysis, given that Internet sales have created a worldwide market for many products, so that actual earnings $100 \%$ higher than forecasts are realistic. For example, music used to be sold by the album with 10 - 12 recordings. Online access to music sites has brought 5 million recordings to each listener.

\section{References}

[1] Elmer-Dewitt, P. (2015) Will Apple Rally Next Week Like Google Did on Friday? http://fortune.com/2015/07/18/apple-revenue-eps-2015q3/ 
[2] Ball, R. and Brown, P. (1968) An Empirical Evaluation of Accounting Income Numbers. Journal of Accounting Research, 6, 159-178. http://dx.doi.org/10.2307/2490232

[3] Nichols, D.C. and Wahlen, J.M. (2004) How Do Earnings Numbers Relate to Stock Returns? A Review of Classic Accounting Research with Updated Returns. Accounting Horizons, 18, 263-286. http://dx.doi.org/10.2308/acch.2004.18.4.263

[4] Talmor, E. (1981) Asymmetric Information, Signaling and Optimal Corporate Financial Decisions. Journal of Financial and Quantitative Analysis, 16, 413-435. http://dx.doi.org/10.2307/2330363

[5] Williamson, S.H. (2016) Annualized Growth Rates and Graphs of the DJIA, S\&P 500 and NASDAQ in the United States between Any Two Dates. www.measuringworth.com

[6] Fama, E.F. and French, K.R. (1989) Business Conditions and Expected Returns on Stocks and Bonds. Journal of Financial Economics, 25, 23-49. http://dx.doi.org/10.1016/0304-405X(89)90095-0

[7] Jensen, M.C. and Meckling, W.H. (1976) Theory of the Firm: Managerial Behavior, Agency Costs and Ownership Structures. Journal of Financial Economics, 3, 305-360. http://dx.doi.org/10.1016/0304-405X(76)90026-X

[8] Barber, B., Lehavy, R., McNichols, M. and Trueman, B. (2001) Can Investors Profit from the Prophets? Security Analysts’ Recommendations and Stock Returns. Journal of Finance, 56, 531-563. http://dx.doi.org/10.1111/0022-1082.00336

[9] Frankel, R., Kothari, P. and Weber, J. (2006) Determinants of the Informativeness of Analyst Research. Journal of Accounting and Economics, 41, 29-54. http://dx.doi.org/10.1016/j.jacceco.2005.10.004

[10] Chung, K.H. and Jo, H. (1996) The Impact of Security Analysts Monitoring and Marketing Functions on the Market Value of Firms. Journal of Financial and Quantitative Analysis, 31, 493-512. http://dx.doi.org/10.2307/2331357

[11] Chen, C.R. and Steiner, T.L. (2000) Tobin's Q, Managerial Ownership, and Analyst Coverage: A Nonlinear Simultaneous Equations Model. Journal of Economics and Business, 52, 365-382. http://dx.doi.org/10.1016/S0148-6195(00)00024-2

[12] Bhushan, R. (1989) Firm Characteristics and Analyst Following. Journal of Accounting and Economics, 11, $255-274$. http://dx.doi.org/10.1016/0165-4101(89)90008-6

[13] Merton, R. (1987) A Simple Model of Capital Market Equilibrium with Incomplete Information. Journal of Finance, 42, 483-510. http://dx.doi.org/10.1111/j.1540-6261.1987.tb04565.x

[14] Hill, C.W.L. and Jones, T.M. (1992) Stakeholder-Agency Theory. Journal of Management Studies, 29, 131-154. http://dx.doi.org/10.1111/j.1467-6486.1992.tb00657.x

[15] Sambharya, R.B. (2011) Security Analysts’ Earnings Forecasts as a Measure of Firm Performance. Management Decision, 49, 1160-1181. http://dx.doi.org/10.1108/00251741111151190

[16] Pfarrer, M.D., Pollock, T.G. and Rindova, V.P. (2010) A Tale of Two Assets: The Effects of Firm Reputation and Celebrity on Earnings Surprises and Investor’s Reactions. Academy of Management Journal, 53, 1131-1152. http://dx.doi.org/10.5465/AMJ.2010.54533222

[17] Agarwal, J. and Malhotra, N.K. (2005) An Integrated Model of Attitude and Affect: Theoretical Foundation and an Empirical Investigation. Journal of Business Research, 58, 483-493. http://dx.doi.org/10.1016/S0148-2963(03)00138-3

[18] Mintzberg, H. and Waters, J.A. (1982) Tracking Strategy in an Entrepreneurial Firm. Academy of Management Journal, 25, 465-499. http://dx.doi.org/10.2307/256075

[19] Datta, S. and Dhillon, U.S. (1993) Bond and Stock Market Response to Unexpected Earnings Announcements. Journal of Financial and Quantitative Analysis, 28, 565-577. http://dx.doi.org/10.2307/2331166

[20] Brennan, M.J. (1991) A Perspective on Accounting and Stock Prices. The Accounting Review, 66, 67-79.

[21] Handjinicolaou, G. and Kalay, A. (1984) Wealth Redistribution of Changes in Firm Value: An Analysis of Returns to Bondholders and Stockholders around Dividend Announcements. Journal of Financial Economics, 13, 35-63. http://dx.doi.org/10.1016/0304-405X(84)90031-X

[22] Lev, B. (1989) On the Usefulness of Earnings and Earnings Research: Lessons and Direction from Two Decades of Empirical Research. Journal of Accounting Research Supplement, 27, 153-192. http://dx.doi.org/10.2307/2491070

[23] Jennings, R.H., Starks, L.T. and Fellingham, J.C. (1981) An Equilibrium Model of Asset Trading with Sequential Information Arrival. Journal of Finance, 36, 143-161. http://dx.doi.org/10.1111/j.1540-6261.1981.tb03540.x

[24] Patell, J.M. and Wolfson, M.A. (1984) The Intraday Speed of Adjustment of Stock Prices to Earnings and Dividend Announcements. Journal of Financial Economics, 13, 223-252. http://dx.doi.org/10.1016/0304-405X(84)90024-2

[25] Jennings, R.H. and Starks, L.T. (1986) Earnings Announcements, Stock Price Adjustment and the Existence of Option Markets. Journal of Finance, 41, 107-125. http://dx.doi.org/10.1111/j.1540-6261.1986.tb04494.X

[26] Woodruff, C.S. and Senchak, A.J. (1988) Intradaily Price-Volume Adjustments of NYSE Stocks to Unexpected Earnings. Journal of Finance, 43, 467-491. http://dx.doi.org/10.1111/j.1540-6261.1988.tb03950.x 
[27] Porter, M.E. (1980) Competitive Strategy: Techniques for Analyzing Industries and Competitors. Free Press, New York.

[28] Ghosh, A., Gu, Z. and Jain, P.C. (2005) Sustained Earnings and Revenue Growth, Earnings Quality, and EarningsResponse Coefficients. Review of Accounting Studies, 10, 33-57. http://dx.doi.org/10.1007/s11142-004-6339-3

[29] Ajinkya, B.B. and Gift, M.J. (1984) Corporate Managers’ Earnings Forecasts and Symmetrical Adjustments of Market Expectations. Journal of Accounting Research, 22, 425-444. http://dx.doi.org/10.2307/2490657

[30] Kama, I. (2009) On the Market Reaction to Revenue and Earnings Surprises. Journal of Business Finance and Accounting, 36, 31-50. http://dx.doi.org/10.1111/j.1468-5957.2008.02121.x

[31] Quinn, M. (2011) The Big Number. http://www.wsj.com/articles/SB10001424052970204524604576609740825745286

[32] Bernstein, L. (1993) Financial Statement Analysis. Irwin, Homewood.

[33] Financial Accounting Standards Board (1980) Summary of the Discussion Memorandum on Reporting Funds Flows, Liquidity and Financial Flexibility. FASB, Stamford.

[34] Houge, T. and Loughran, T. (2000) Cash Flow is King? Cognitive Errors by Investors. Journal of Psychology and Financial Markets, 1, 161-175. http://dx.doi.org/10.1207/s15327760jpfm0134 2

[35] Odean, T. (1998) Volume, Volatility, Price, and Profit when All Traders Are above Average. Journal of Finance, 53, 1887-1934. http://dx.doi.org/10.1111/0022-1082.00078

[36] Clark, N.K. and Rutter, D. (1985) Social Categorization, Visual Cues, and Social Judgments. European Journal of Social Psychology, 15, 105-119. http://dx.doi.org/10.1002/ejsp.2420150108

[37] Kahneman, D. and Tversky, A. (1973) On the Psychology of Prediction. Psychological Review, 80, $237-251$. http://dx.doi.org/10.1037/h0034747

[38] Taylor, S.E. and Thompson, S. (1982) Stalking the Elusive “Vividness” Effect. Psychological Review, 89, 155-191. http://dx.doi.org/10.1037/0033-295X.89.2.155

[39] Fischer, D. (2012) Investor Underreaction to Earnings Surprises and Overreaction to Product News in the Drug Industry. Journal of Business and Economic Studies, 18, 82-90.

[40] Nisbet, R. and Ross, L. (1980) Human Inference: Strategies and Shortcomings of Social Judgment. Prentice-Hall, Englewood Cliffs.

[41] Roethlisberger, F. (1968) Man in Organization. Harvard University Press, Cambridge. http://dx.doi.org/10.4159/harvard.9780674420564

[42] Kinney, W., Burgstahler, D. and Martini, R. (2002) Earnings Surprise “Materiality” as Measured by Stock Returns. Journal of Accounting Research, 40, 1297-1329. http://dx.doi.org/10.1111/1475-679X.t01-1-00055

\section{Submit or recommend next manuscript to SCIRP and we will provide best service for you:}

Accepting pre-submission inquiries through Email, Facebook, Linkedin, Twitter, etc A wide selection of journals (inclusive of 9 subjects, more than 200 journals)

Providing a 24-hour high-quality service

User-friendly online submission system

Fair and swift peer-review system

Efficient typesetting and proofreading procedure

Display of the result of downloads and visits, as well as the number of cited articles

Maximum dissemination of your research work

Submit your manuscript at: http://papersubmission.scirp.org/ 